\title{
A tengeri kalózkodásra vonatkozó nemzetközi jogi rezsim
}

\author{
The International Legal Framework of Maritime Piracy
}

\begin{abstract}
ABSZTRAKT
Habár a tengeri kalózkodás a legrégebbi, tengeren elkövetett büncselekmény, még mind a mai napig jelen van, és komoly veszélyforrásnak számít. Amellett, hogy emberi életeket is veszélyeztet, károkat okoz a nemzetközi kereskedelemnek is. A deliktummal szembeni fellépés legfontosabb elemei közé tartoznak azok a nemzetközi egyezmények, amelyek meghatározzák annak fogalmát, tipikus elkövetési magatartásait, valamint eljárási rendelkezéseket is tartalmaznak a kalózkodás visszaszorítása érdekében. Jelenleg ezt a nemzetközi jogban két egyezmény biztosítja, amelyek számos kérdést megfelelöen szabályoznak, azonban hiányosságokkal is küzdenek. Tanulmányomban e két szerződésnek a kalózkodásra vonatkozó rendelkezéseit vizsgálom.
\end{abstract}

Kulcsszavak: tengeri kalózkodás, nemzetközi jog, nemzetközi büntetőjog, tengerjog

\begin{abstract}
Although maritime piracy is the oldest crime committed at sea, it is still present to this day and counts as a threat: it not only endangers human lives but also causes damage to international trade. Firm actions must be taken against this international crime and those international agreements which define the definition and the elements of conduct of maritime piracy and also contain procedural provisions to suppress it count as vital elements of these actions. Currently there are two agreements which contain anti-piracy regulations and they regulate several matters appropriately but they have many shortcomings. In this article I examine the anti-piracy regulations of these agreements.
\end{abstract}

Keywords: maritime piracy, international law, international criminal law, law of the sea

A kalózkodás a legrégebbi, tengeren elkövetett bủncselekmény, amely a 21 . században is jelen van, és komoly kihívást jelent az államoknak és a nemzetközi tengeri kereskedelemnek. A kalózkodás visszaszorítása érdekében folytatott küzdelemben a nemzetközi közösség leghatékonyabb fegyvere egy olyan jogi rezsim kialakítása lenne, amely megfelelő alapokat szolgáltat az elkövetők felelősségre vonására, akár nemzeti, akár nemzetközi szinten. Ennek alapja pedig egy minden szempontból kielégítő, egyetemesen elfogadott kalózkodás-definíció, valamint azoknak a gyakorlati szabályoknak a pontos körülírása, amelyek az államok jogait és lehetőségeit részletezik a kalózok elfogásakor.

\footnotetext{
* Dr. Pászka Imre Ágoston, PhD-hallgató, Szegedi Tudományegyetem Állam- és Jogtudományi Kar, Nemzetközi Jogi és Európa-jogi Tanszék, e-mail: paszkai@juris.u-szeged.hu.
} 
Ezeket a szabályokat nemzetközi jogban jelenleg két egyezmény hivatott biztosítani. Az egyik az ENSZ Tengerjogi Egyezménye (United Nations Convention on the Law of the Sea - UNCLOS), amely egy széles körben ratifikált dokumentum, amelynek föbb rendelkezései a nemzetközi szokásjog részét képezik, és amely saját definícióval is rendelkezik. A deliktum fogalmi rendszere leginkább erre támaszkodik, valamint számos nemzetközi megállapodás is ezt a meghatározást vette át. A nemzetközi jogi rezsim másik fontos elemét $A$ tengerhajózás biztonsága elleni jogellenes cselekmények visszaszorításáról szóló egyezmény (Convention for the Suppression of Unlawful Acts against the Safety of Maritime Navigation - SUA) képezi, amelynek megalkotását elsősorban az UNCLOS fogalmi hiányosságai indokolták, amelyeket nagyrészt képes is javítani.

Tanulmányomban a tengeri kalózkodásra vonatkozó nemzetközi jogi rezsimet, azaz az említett két egyezmény rendelkezéseit vizsgálom. Ezen belül kritikai szemszögböl foglalkozom ezek fogalmi rendszerével, valamint azokat a gyakorlati szabályokat is bemutatom, amelyek a kalózok elfogását hivatottak elősegíteni.

\section{A tengerjogi egyezményt megelőző kodifikációs törekvések}

A tengeri kalózkodás - a nemzetközi szokásjog szerint - a legrégebbi olyan nemzetközi bűncselekmény, amely univerzális joghatóság alá tartozik, azaz bármely állam gyakorolhatja a joghatóságát, függetlenül az elkövető állampolgárságától vagy az elkövetés helyétöl. ${ }^{1}$ Mivel a kalózok már az ókorban is jelen voltak, és válogatás nélkül fosztogatták minden nép hajóit, ezért az akkoriban uralkodó közfelfogás szerint az emberiség ellenségeinek (hostis humani generis) minősültek, emiatt pedig bárki elfoghatta és felelösségre vonhatta őket. ${ }^{2}$

A kalózkodás fogalma a nemzetközi együttmüködés megerösödése előtti időszakban államonként eltérő volt. Az azonban közös pontként volt megfigyelhető az egyes államok belső jogában, hogy a kalózkodást tengeren elkövetett rablásként közelítették meg, amely feltételezi az animus furandit, azaz a lopási, rablási szándékot. Az 1920-as években egy, a Harvardon végzett kutatás úgy fogalmazott, hogy különbséget kell tenni a kalózkodás nemzetek joga szerinti, és az egyes belső jogok szerinti definíciója között. ${ }^{3}$

Az első világháborút követően több nemzetközi megállapodásban (vagy azok tervezeteiben) tettek kísérletet a kalózkodás fogalmának körülhatárolására. Az első meghatározást a Harvard jogi karán létrejött nemzetközi jogi kutatócsoport alkotta meg, amely a Nemzetek Szövetségének munkáját kívánta segíteni. 1932-re készültek el a kalózkodásellenes egyezmény tervezetével, amelynek több rendelkezése is visszaköszön az ENSZ keretében elfogadott egyezményekben. Így például a Nyílt Tengeri Konvenció és a Tengerjogi Egyezmény kalózkodás definíciója több elemé-

${ }^{1}$ DutTon, Yvonne M.: Bringing Pirates to Justice: A Case for Including Piracy within the Jurisdiction of the International Criminal Court. Chicago Journal of International Law, 2010/1, 203-204. (DOI: 10.31228/osf.io/ztdvm)

2 VARGA Attila Ferenc: Kísérletek és eredmények a kalózkodás definíciójának meghatározásában. Hadtudományi szemle, 2011/1, 30-33.

${ }^{3}$ BoIster, Neil: An Introduction to Transnational Criminal Law. Oxford University Press, Oxford, $2018,47$. 
nek is a Harvard jogászai által meghatározottak szolgáltak alapul, azok minden - később ismertetendő - hibájával és hiányosságával együtt. ${ }^{4}$

1937-ben fogadták el a nyoni egyezményt a Földközi-tengeren elkövetett kalózcselekmények elleni küzdelem jegyében, amely konkrétan kiemelte a tengeralattjárók kalóztevékenységét, mint olyat, amellyel szemben a részes államoknak fel kell lépniük. Az érdekesség ezzel kapcsolatban az, hogy a kalózkodás fogalmát kiterjesztették a nem magáncélból elkövetett támadásokra is. Ezzel ellentétesen azonban 1956-ban az ENSZ Nemzetközi Jogi Bizottsága azt mondta ki, hogy kizárólag magántulajdonban lévő, magáncélból eljáró hajók követhetik el a kalózkodás bűncselekményét. A nemzetközi jogban a későbbi fogalmi meghatározási kísérletekre szintén ez az álláspont volt a jellemző. ${ }^{5}$

A tengerjog - és ezen belül a tengeri kalózkodás - definícióinak meghatározásában fontos lépcső volt az ENSZ Közgyülés által létrehozott Tengerjogi Konferencia, amelynek keretében 1958-ban négy egyezményt fogadtak el Genfben, köztük a Nyílt Tengeri Konvenciót, ami a tengeri szokásjogot kodifikálta. A Konvencióban rögzített kalózkodás-fogalom szolgált az UNCLOS definíciójának alapjául, és gyakorlatilag megegyezik vele, ezért ennek bemutatására a későbbiekben térek ki. Azonban azt fontos már most kiemelni, hogy a kalózkodás megkülönböztető ismérve a Konvenció szerint is a magáncélból történő elkövetés. Ezt azért hangsúlyozták, mert el akarták kerülni, hogy politikai célokra is fel lehessen használni az univerzális joghatóságot, így csökkentve az államok közötti konfliktusok kialakulásának veszélyét. ${ }^{6}$ Ezt a feltételt kifogásolta - a többi, egykor a keleti blokkhoz tartozó szocialista országhoz hasonlóan - Magyarország is, amely fenntartást fủzött a Konvencióhoz, azt hiányolva, hogy az nem tiltja az állami kalózkodást, vagyis amelyet az állam hadihajókkal követ el, mivel ezt tartották a kalózkodás összes formája közül a nemzetközi békére legveszélyesebbnek. ${ }^{7}$

\section{Az ENSZ Tengerjogi Egyezménye}

Az ENSZ Tengerjogi Egyezményét majdnem tízévi egyeztetést követően, 1982-ben fogadták el és írták alá a jamaicai Montego Bay-ben. Ez váltotta fel az 1958-ban elfogadott négy genfi egyezményt, valamint modernizálta és kiterjesztette azok rendelkezéseit olyan területekre is, amelyek korábban nem képezték a szabályozás tárgyát (például a tengeri szennyezés különböző esetei). Az UNCLOS jelentősége továbbá, hogy három olyan szervet is létrehozott, amelyek a tengerjoghoz kapcsolódó kérdések értelmezésére vagy viták eldöntésére hivatottak: a Nemzetközi Tengerjogi Törvényszéket, a Nemzetközi Tengerfenék Hatóságot és a Kontinentális Talapzat Bizottságot. $^{8}$

\footnotetext{
${ }^{4}$ Lanuza Avello, Juan: Prosecution of Piracy at Sea. Lambert Academic Publishing, Saarbrücken, 2016, 14-15.

${ }^{5}$ LANuZa AVEllo: i. m., 33-34.

${ }^{6}$ VARGA: i. m., 36-38.

7 SzALAI Anikó: Érdekességek a nemzetközi szerződésekhez tett magyar fenntartások köréből. Ars Boni, 2017/1-2, 17-18.

${ }^{8}$ United Nations Convention on the Law of the Sea - Further Information, https://www.iucn.org/sites/dev/files/ unclos_further_information.pdf (2019.12. 27.).
} 
Az egyezmény 1994 novemberében lépett hatályba, és jelenleg 168 részes állama van. A legfontosabb állam, amelyik nem ratifikálta, kétségkívül az Egyesült Államok, amely a tengerfenéken található természeti erőforrások nemzeti joghatóságon kívüli kiaknázására vonatkozó szabályozás miatt maradt távol. Ez azonban nem jelenti azt, hogy az UNCLOS szabályai alól teljesen kivonná magát, hiszen az egyezmény föbb rendelkezései a nemzetközi szokásjog részét képezik, valamint az USA bizonyos rendelkezéseket maga is átültetett a belső jogába (például a kizárólagos gazdasági övezetre vonatkozó szabályokat). ${ }^{9}$

Ami Magyarországot illeti, 1982. február 5-én hazánk is aláírta az egyezményt, amit az ENSZ nyilvántartása szerint 2002-ben ratifikáltunk is, azonban kihirdetése mind a mai napig nem történt meg. ${ }^{10}$ Mivel azonban, mint említettem, az egyezmény föbb rendelkezései a nemzetközi szokásjog részét képezik, így azok aláírás vagy ratifikálás hiányában is kötelezők a nemzetközi jog alanyaira.

\section{Az ENSZ Tengerjogi Egyezményének kalózkodásra vonatkozó szabályozása}

Az UNCLOS 100. cikke mondja ki az összes állam kötelezettségét, hogy együttműködjenek más országokkal a nyílt tengeri kalózkodás visszaszorítása érdekében, ideértve az összes olyan vízfelületet, ami nem tartozik egyetlen állam parti vizeihez. ${ }^{11} \mathrm{~A}$ rendelkezéshez füzött kommentár kimondja, hogy az együttmüködési kötelezettség be nem tartása nemzetközi jog kötelezettségszegésnek minősül. ${ }^{12}$ A 101. cikk tartalmazza a kalózkodás definícióját, amelyet később részletesebben is áttekintek. A 102. cikk azt mondja ki, hogy amennyiben a kalózcselekményeket olyan jármü felhasználásával követik el, amely valamely állam haditengerészetéhez vagy légierejéhez tartozik, és amelynek legénysége fellázadt vagy magához ragadta e jármű irányítását, az elkövetők cselekményeit a „közönséges” kalózkodásra vonatkozó szabályok szerint kell megítélni. A 103. cikk megadja a kalózjármü fogalmát (amely nyilvánvalóan lehet vízi és légi jármü is).

A 104. cikk a kalózjárművek nemzeti hovatartozásának megtartásával és elvesztésével foglalkozik. A 105. cikk rendelkezik a kalózjármű elfogásáról, kifejezve, hogy a büncselekmény univerzális joghatóság alá tartozik. A 106. cikk a jogalap nélküli elfogás esetén alkalmazandó szabályokat tartalmazza. Az egyezmény 107. cikke pedig azt mondja ki, hogy az elfogást csak valamely állam hadihajói vagy katonai légi jármüvei foganatosíthatják. Ezek mellett fontos még megemlíteni a 110. és a

${ }^{9}$ United Nations Convention on the Law of the Sea - Further Information, https://www.iucn.org/sites/dev/files/ unclos_further_information.pdf (2019. 12. 27.).

${ }^{10}$ Szalai Anikó: Kutatói blog 5/18. A kalózkodással kapcsolatos magyar fenntartás. 2018., https://drszalaianiko. hu/tag/tengerjog/ (2019. 12. 27.).

${ }^{11}$ Az ENSZ Tengerjogi Egyezménye 100. cikk. H/5558.számú országgyülési határozati javaslat. (A továbbiakban: az ENSZ Tengerjogi Egyezménye.)

${ }^{12}$ KISS Amarilla: A tengeri kalózkodás nemzetközi jogi megítélése, különös tekintettel a Szomália partjainál folyó eseményekre. Acta Universitatis Szegediensis: Acta Juridica et Politica: Publicationes Doctorandorum Juridicorum, 2009/9, 213. 
111. cikket, amelyek az átvizsgálás és az üldözés jogáról szólnak, ezáltal a kalózkodás visszaszorítása érdekében foganatosítható gyakorlati intézkedéseket bővítik a 105. cikk mellett. ${ }^{13} \mathrm{Az}$ UNCLOS szabályai tehát gyakorlatilag azt részletezik, mi is a kalózkodás, milyen jármüvet tekinthetünk kalózjármünek, és hogyan történhet egy kalózjármű elfogása; emellett a harmadik felek érdekeit is védelmezi, ${ }^{14}$ valamint egyes gyakorlati szabályokat tartalmaz a kalózkodás felderítése érdekében.

\section{Az ENSZ Tengerjogi Egyezményének 101. cikke}

Mint már említettem, az egyezmény 101. cikke meghatározza a kalózkodás fogalmát. Mivel az UNCLOS-nak 168 részes állama van, illetve a nemzetközi szokásjog részét képezi, így az ebben a cikkben foglalt definíció tekinthető a deliktumra vonatkozó jogi rezsim alapjának.

A fogalom elemei a következök:

a) az elkövetett cselekmény jogellenes, erőszakos, feltartóztatásra irányuló vagy fosztogató (az erőszak követelménye);

b) magáncélból történő elkövetés (a magáncél követelménye);

c) az elkövetők magántulajdonban lévő hajó vagy légi jármü személyzete vagy utasai (a magánhajó követelménye);

d) a cselekményt egy másik hajó vagy légi jármü „sérelmére”, vagy az azon lévő személyek vagy vagyontárgyak sérelmére követik el (a két hajó követelménye);

e) az elkövetés helye nyílt tenger (a nyílt tenger követelménye).

Fontos továbbá azt is kiemelni, hogy az UNCLOS 101. cikke szerint a kalózhajó üzemben tartója, valamint a részesi magatartást kifejtỏ is elköveti a büncselekményt.

A következőkben a fenti feltételeket részletesebben is megvizsgálom.

\subsection{Az eröszak követelménye}

Az első követelményt röviden az eröszak követelményeként lehet körülírni. Az UNCLOS ugyanis a kalózkodás egyfajta elöfeltételeként határozza meg, hogy a jogellenes cselekménynek erőszakosnak, feltartóztatásra irányulónak vagy fosztogatónak kell lennie. Ezek tehát szándékosságot feltételeznek, azt viszont nem részletezi az egyezmény, hogy pontosan mit kell érteni alattuk.

Azt egyértelművé teszi a rendelkezés, hogy az erőszakos magatartások bármelyikével megvalósul a kalózkodás, hiszen vagylagos felsorolással határozza meg az elkövetési magatartásokat. Ugyanakkor nem tisztázott, hogy az erőszakos cselekmény már önmagában kalózkodásnak minősül-e (amennyiben természetesen a fogalom további négy feltétele is teljesül), vagy van egy minimumszint, amit az

\footnotetext{
${ }^{13}$ Az ENSZ Tengerjogi Egyezménye 101-107.; 110-111. cikk.

${ }^{14}$ QURESHI, Waseem Ahmad: The Prosecution of Pirates and the Enforcement of Counter-Piracy Laws Are Virtually Incapacitated by Law Itself. San Diego International Law Journal, 2017/1, 104.
} 
erőszaknak el kell érnie. Ez a kérdés általában két gyakorlati példa révén szokott felmerülni: a halászhajók közti összezördüléseken, és a környezetvédők egyes akcióin („eco-piracy”) keresztül. ${ }^{15}$

Előbbieket elrettentési célzattal szokták elkövetni - még napjainkban is ${ }^{16}$-, föként, hogy távol tartsák az idegen hajókat a parti állam kizárólagos gazdasági övezetétől. Példaként említhető, hogy az Írországhoz tartozó vizeken 1994 és 1999 között ötven ilyen incidens történt, amelyek többnyire a hajók összeütközésében és a halászhálók megrongálásában álltak. Erre reagálva az ír kormány 2001-re megfogalmazott egy törvényjavaslatot, amely, az UNCLOS szabályaira építve, a hasonló cselekményeket kalózkodásnak minősítette volna, ám végül a javaslatot elvetették, főként azért, mert sem a cselekmények súlya, sem az elkövetők társadalomra veszélyessége nem volt olyan mértékü, amit a kalózkodás „megkövetel”. ${ }^{17}$

A környezetvédők által elkövetett cselekmények elkövetési módjai nagyban hasonlítanak a halászokéhoz, azaz általában a hajók megrongálásáig terjednek. Ugyanakkor ennek túllépése esetén már nem kizárt, hogy a bíróságok kalózkodást állapítsanak meg. Erre példa a Sea Shepherd-ügy (amellyel a magáncél követelményénél részletesebben is foglalkozom) amelyben az elkövetök gyúlékony és savval töltött eszközökkel dobálták meg a bálnavadász-hajót, ami már egyértelmüen kimerítette az UNCLOS-ban foglalt feltételeket. Azt, hogy az erőszak követelményének egy meghatározott mértéket el kell érnie a kalózkodás megállapításához, a szomáliai elkövetők ügyeit tárgyaló bíróságok döntései is alátámasztják. Ugyanakkor ezek olykor igen alacsony küszöböt szabtak, hiszen már az is elegendő volt, ha a támadók tüzet nyitottak a hajóra vagy a legénységre, de lövéseik nem találtak célba. ${ }^{18}$

Az UNCLOS definíciója szerint az elkövetett cselekménynek jogellenesnek is kell lennie. Ezt a joghatóságot gyakorló állam joga szerint kell megítélni, ami magában foglalja természetesen azt is, hogy jogellenességet kizáró ok sem állhat fenn a vonatkozásukban. ${ }^{19} \mathrm{Az}$ erőszakos magatartásra vonatkozó, általánosan elfogadott tudományos értelmezés szerint az irányulhat a megtámadott hajó legénysége, vagy a hajón lévő vagyontárgyak ellen is. Emellett a 101. cikk nem szól a kalózcselekmény kísérletéröl, így azt tételezhetjük föl, hogy az kívül esik az egyezmény szerinti kalózkodás körén. ${ }^{20}$

\subsection{A magáncél követelménye}

A magáncélból történő elkövetés feltételét szintén nem részletezi jobban az egyezmény. Mint már említettem, az ENSZ-ben ez volt az általánosan elfogadott

${ }^{15}$ CHURCHILL, Robin: Chapter 1. The Piracy Provisions of the UN Convention on the Law of the Sea. In: Koutrakos, Panos-Skordas, Achilles (eds): The Law and Practice of Piracy at Sea. Hart Publishing Ltd., Oxford, 2015, 13-14. (DOI: 10.5040/9781474201759.ch-001).

${ }^{16}$ Scallop war: French and British boats clash in Channel. https://www.bbc.com/news/world-europe-45337091 (2020. 01. 06.).

17 ChURChILL: i. m., 14.

18 CHURCHILL: i. m., 14-15.

$166{ }^{19}$ BOISTER: i. m., 48.

${ }^{20}$ QURESHI: i. m., 105. 
vélemény már a genfi egyezmények idején is, oka pedig az, hogy politikai célokra ne lehessen felhasználni az univerzális joghatóságot.

Az ENSZ Nemzetközi Tengerészeti Szervezete (International Maritime Organization - IMO) jogi bizottságának álláspontja és az állami gyakorlat is azt látszik alátámasztani, hogy a magáncélból történő elkövetés a kalózkodás keretei között a személyes haszonszerzésre irányultságot jelenti. ${ }^{21} \mathrm{~A}$ haszon szempontjából irreleváns, hogy az a hajóról eltulajdonított áruk eladásából, a legénység szabadon engedéséért kapott váltságdíjból, vagy esetleg mindkettőből származik. Ez a követelmény tehát főszabály szerint kizárja azokat a támadásokat, amelyeket egy állam vagy egy politikai szervezet felügyelete alatt követnek el. Ennek következtében az említett entitások irányítása alatt a tengeren elkövetett terrorcselekmények - amelyek politikai motivációjúak - nem tartoznak az UNCLOS fogalmi körébe, még akkor sem, ha a kalózkodásra vonatkozó egyéb feltételek teljesülnek. ${ }^{22}$

A magáncél értelmezésével összefüggésben az állam szerepe és a politikai célzat vizsgálata kapcsán két iskola is kialakult. Az első szerint azok a jogellenes cselekmények, amelyek egyébként kalózkodásnak minősülnének, de amelyeket természetükben politikai, vagy szorosan egy államhoz kapcsolódó célból követnek el, nem tartoznak a kalózkodás fogalma alá. $E$ felfogás szerint tehát a célzat kerül a vizsgálat középpontjába, ami igencsak szubjektívvá teszi annak eldöntését, hogy történt-e kalózkodás. A másik értelmezés szerint magáncéllal valósul meg az elkövetés, ha azt semmilyen módon nem támogatta egy állam. Ezen értelmezés szerint például az egyes felkelő csoportok által, politikai célzattal elkövetett cselekmények is kalózkodásnak minősülhetnek. ${ }^{23}$

A két iskola közti véleményellentét a gyakorlatban is megmutatkozott. 1961-ben a portugál Santa Maria hajót a fedélzetén utazó felkelők foglalták el, a saját politikai céljaikból. A hajóval végül Brazíliába hajóztak. A portugál hatóságok a magáncél követelményére hivatkozva kalózkodásként kezelték az ügyet, Brazília viszont menedékjogot adott az elkövetőknek. A Santa Maria-ügyet végül a két hajó követelményének hiányában a jogtudomány nem minősítette kalózkodásnak, azonban a magáncél vizsgálatának szempontjából fontos jelentőséggel bír. Egyes vélemények szerint ebben az esetben a magáncél követelménye azért nem teljesült, mert az elkövetők politikai céljait azok motivációjának és az adott állammal való kapcsolatuknak fényében kell vizsgálni. Ezért ebben az esetben kalózkodásról nem beszélhetünk, ami azonban nem jelenti azt, hogy más büncselekmény miatt az elkövetők ne lehetnének felelősségre vonhatók. ${ }^{24}$ Erre az álláspontra azonban a következő ügyek erősen rácáfoltak.

Az 1986-os Castle John v. NV Babeco ügyben a Greenpeace aktivistái foglaltak el és rongáltak meg két holland hajót, amelyek a tengervizet szennyezték. A belga kasszációs bíróság ezeket a magatartásokat magáncélból elkövetettnek, ezáltal pedig

\footnotetext{
${ }^{21}$ BOISTER: i. m., 50.

22 Hodgkinson, Sandra L.: The Governing International Law on Maritime Piracy. In: Scharf, Michael P.-Newton Michael A.-Sterio, Milena (eds): Prosecuting Maritime Piracy. Cambridge University Press, New York, $2015,18$.

${ }^{23}$ QURESHI: i. m., 106.

${ }^{24}$ QUershI: i. m., 106-107.
} 
kalózkodásnak minősítette. Az egyik amerikai fellebbviteli bíróság előtti, 2013-as Sea Shepherd-ügy hozott aztán elörelépést az értelmezésben. A Sea Shepherd Conservation Society tagjai japán bálnakutató hajókat rongáltak meg az állatok védelme érdekében. A bíróság kalózkodásnak minősítette ezt a cselekményt, és indokolásában a következőképp fogalmazott:

A magáncélból történő elkövetés magában foglalja azokat az eseteket, amikor az elkövetők személyes, morális vagy filozófiai alapon cselekszenek, ideértve a Sea Shepherd tagjai által vallott természetvédelmi célokat is. Az, hogy az elkövetők a saját véleményük szerint közérdekböl cselekednek, még nem jelenti azt, hogy az ténylegesen így is van. ${ }^{25}$

Áláspontom szerint a Sea Shepherd-ügyben megfogalmazott indokolás helytálló, és lényeges kiindulópontja az értelmezésnek. Ugyanakkor a személyes haszonszerzési jelleg - amely a magáncélból történő elkövetés kiindulópontja kellene hogy legyen - sem ebben, sem a Babeco-ügyben nem volt megállapítható, tehát összességében a bíróságok mégis tévesen minősítették ezeket az eseteket kalózkodásnak. Környezetvédelmi aktivisták cselekményeit kalózkodásnak minősíteni pedig szintén hibás, hiszen alapvető motivációik és társadalomra veszélyességük nagyban különbözik a Délkelet-Ázsiában vagy Nigériában büncselekményeket elkövető, valódi kalózokétól. Az a tény, hogy ennek ellenére, az egyezmény szövege alapján mégis egy esetkörbe vonható a kettő, szintén az UNCLOS hiányosságaira mutat rá, hiszen fogalma nem tartalmaz mens rea elemet, amely alapján az elöbbi cselekmények más besorolás alá eshetnének.

A magáncélból történő elkövetés tehát egyetemesen elfogadott értelmezéssel továbbra sem rendelkezik, és mindaddig, amíg ez így van, hasonló problémás esetekkel fogunk találkozni a gyakorlatban.

\subsection{A magánhajó követelménye}

A harmadik feltétel szerint az elkövetők magántulajdonban lévő hajó vagy légi jármű személyzete vagy utasai. Ez főszabály szerint azt jelenti, hogy a támadó jármü nem lehet például hadihajó. Azok az államok, amelyek a katonai akcióik keretein belül hajtanak végre kalózkodáshoz hasonló cselekményeket, a nemzetközi jog más szabályai alapján lesznek felelősségre vonhatók. ${ }^{26}$

Ugyanakkor az egyezmény a 102. cikkében a magánhajó követelményével kapcsolatban azt a kiegészítést teszi, hogy ha egy hadihajó vagy katonai légi jármü legénysége fellázad és kalózcselekményt követ el, akkor szintén magántulajdonban lévőnek, ezáltal pedig kalózhajónak kell tekinteni. ${ }^{27}$ Viszont az elkövetők cselekményei ebben az esetben sem lesznek betudhatóak az államnak. ${ }^{28}$ Az UNCLOS a 103.

\footnotetext{
${ }^{25}$ QURESHI: i. m., 107-108.

${ }^{26}$ HODGKINSON: i. m., 18-19.

${ }^{27}$ Az ENSZ Tengerjogi Egyezménye 102. cikk.

${ }^{28}$ Szalai (2017): i. m., 18.
} 
cikkben kimondja azt is, hogy egy jármű akkor tekinthető kalózjármünek, ha felhasználásával a 101. cikkben meghatározott cselekményeket követnek el. ${ }^{29}$

\subsection{A két hajó követelménye}

A negyedik feltétel szerint két jármünek kell érintettnek lennie: amelyikről végrehajtják a büncselekményt, illetve amelyiken teszik azt. Ebből egyértelmüen látszik, hogy ha egy hajó utasai eltérítik a hajót, amin utaznak, az nem minősül kalózkodásnak az UNCLOS szerint. Ezt támasztja alá az Achille Lauro incidens is 1985-böl, amely nagyban hozzájárult a SUA elfogadásához, ezért azzal a későbbiekben részletesen is foglalkozom. A két hajó követelménye akkor nem teljesült, ezért az esetet nem minősítették kalózkodásnak. Ugyanez igaz a már említett Santa Maria-ügyre is. Ez a két ügy tökéletesen rámutat a két hajó követelménye jelenlegi szabályozásának elégtelenségére. Továbbá azt is meg kell említeni, hogy az eltérítés - mint tipikusan a jármú utasai által megvalósított elkövetési magatartás - nem szerepel az egyezmény 101. cikkében meghatározott erőszak feltételrendszerében. ${ }^{30}$

A két hajó követelményének másik eleme, hogy a nyílt tenger mint elkövetési hely itt is hangsúlyosan megjelenik, hiszen az egyezmény szerint e feltétel teljesüléséhez az is szükséges, hogy a támadó hajó is a nyílt tengeren legyen. Eszerint ha a támadás megindítása a parti tengerről történik, az nem valósítja meg az UNCLOS alá tartozó kalózkodást. ${ }^{31}$

\subsection{A nyílt tenger követelménye}

Az UNCLOS úgy rendelkezik, hogy kalózkodásnak csak a nyílt tengeren elkövetett kalózcselekmények minősülhetnek. Ez pedig azt jelenti, hogy a bűncselekmény fogalmilag nem követhető el olyan vizeken, amelyek valamely állam joghatósága alá tartoznak, például a parti tengeren. ${ }^{32}$

A kalózkodás elkövetési helyének nyílt tengerre való korlátozása a tengereken elkövetett jogellenes cselekmények nagy részét kirekesztette a nemzetközi szabályozásból. Ezt a nemzetközi közösség is gyorsan észlelte, és próbálta orvosolni. A Nemzetközi Tengerészeti Szervezet keretein belül 1988-ban elfogadták a SUA-t, amellyel a továbbiakban részletesebben is foglalkozom. Emellett az IMO Közgyúlése 2009-ben, az 1025(26) számú határozatában különbséget tett kalózkodás és hajók elleni fegyveres rablás között. Utóbbi elkövetési magatartásainak köre tágabb (kiterjed például az eltérítésre is), illetve elkövetési helyeként kifejezetten megjelölték a szigetközi és a parti tengereket. ${ }^{33}$ Ezek az intézkedések tehát azt célozzák, hogy

\footnotetext{
${ }^{29}$ Az ENSZ Tengerjogi Egyezménye 103. cikk.

30 QURESHI: i. m., 109-110.

31 HODGKINDSON: i. m., 21-22.

32 QURESHI: i. m., 110.

${ }^{33}$ International Maritime Organization Assembly Resolution A.1025(26) http://www.imo.org/en/KnowledgeCentre/IndexofIMOResolutions/Assembly/Documents/A.1025(26).pdf (2019. 04. 20.).
} 
azok a cselekmények, amelyek az UNCLOS szabályai szerint nem minősülnének kalózkodásnak, más jogalapon büntethetők legyenek. Problémát jelenthet ugyanakkor, hogy az IMO Közgyülése által elfogadott határozat soft law jogforrási erővel bír, és az államok számára nem kötelező.

Ennek köszönhető, hogy a nyílt tenger követelményének feloldására egyedi esetben is sor került, mégpedig a szomáliai kalózkodás kapcsán, ahol az egyezmény szabályozása szintén nem tette lehetővé a hadihajóknak azon kalózok üldözését, akik a szomáliai területi vizeken követték el a támadásokat. Az ENSZ Biztonsági Tanácsa az Alapokmány VII. fejezetében meghatározott hatáskörében eljárva hozta meg 1861. számú határozatát, amelyben felhatalmazta a szomáliai átmeneti szövetségi kormánnyal együttműködő államokat, hogy minden szükséges intézkedést tegyenek meg az ország területi vizein folyó kalózkodás visszaszorítása érdekében. A határozat jelentősége, hogy az UNCLOS elkövetési helyre vonatkozó szabályait terjesztette ki a területi vizekre. ${ }^{34}$

Egyes államok ugyanakkor az aggodalmukat fejezték ki a határozat elfogadása előtt, hogy annak kiterjesztő értelmezése máshol is lehetővé tenné a hasonló beavatkozást, ezáltal pedig szuverenitásuk veszélybe kerülne. Erre azonban nem kerülhetett sor, hiszen a határozatot a szomáliai kormány kezdeményezte, és az abban foglalt hatásköröket csak a beleegyezésével lehetett gyakorolni. Továbbá a határozat kifejezetten szólt arról is, hogy nem célja a nemzetközi szokásjog fejlesztése azáltal, hogy tágítja vagy szűkíti az UNCLOS részes államainak jogait vagy kötelezettségeit. Emellett a határozat korlátozott időbeli hatállyal is bírt, hiszen a felhatalmazást eredetileg fél évre adta meg. A szomáliai kormány kérésére azonban ezt többször is meghosszabbították, sőt később kiterjesztették a kalózok szomáliai szárazföldön való üldözésére is. ${ }^{35}$

\subsection{Az UNCLOS fogalmi rendszeréből fakadó nehézségek}

Összességében tehát az UNCLOS öt konjunktív kritériumot támaszt ahhoz, hogy egy cselekmény kalózkodásnak minősüljön. Véleményem szerint ezek a követelmények több esetben is nehezen teljesíthetők, ez pedig az elkövetők előnyére válik, és megnehezíti a büncselekmény visszaszorítását. A két hajó követelménye sok esetet zár ki az egyezmény szerinti kalózkodás köréből. Emellett problémás feltétel a magáncélból történő elkövetés is, amelynek egyrészt a pontos tartalma sem tisztázott, másrészt a történelem során számos példát láthattunk arra, ${ }^{36}$ hogy az államok az egymás közötti konfliktusaikban is igénybe vették kalózok segítségét saját politikai céljaik elérése érdekében, ami egyértelműen igazolja, hogy kalózkodni nem csak magáncélból lehet. Szintén aggályosnak tartom az elkövetési hely korlátozottságát, hiszen a jelenleg leginkább veszélyes kalózkodási gócpontokon - Délkelet-Ázsiában és a Guineai-öbölben - a támadások jelentős részét a parti tengeren, sőt, folyótor-

${ }^{34}$ Hodgkinson: i. m., 20.

35 Hodgkinson: i. m., 20-21.

${ }^{36}$ Elég csak az európai uralkodók által kibocsátott kalózlevelekre gondolni, amik legitimálták egyes kalózok cselekményeit. 
kolatokban követik el. Igaz, hogy erre megoldást szolgáltathat a SUA és a hajók elleni fegyveres rablás tényállásának megalkotása, de álláspontom szerint a legfontosabb tengerjogi jogforrásnak pontosabban és átfogóbban kellene szabályoznia azt a büncselekményt, amely a legnagyobb veszélyt jelenti a tengeri kereskedelemre és a hajók legénységének életére.

Az UNCLOS megalkotásakor a részes államok azt feltételezték, hogy mivel a tengeri kalózkodás a nemzetközi szokásjog szerint bűncselekménynek számít, ezért nincs szükség a szerződésben explicite kriminalizálni azt ahhoz, hogy a nemzeti jogok büntető törvényei is így tegyenek. Ennek következtében az egyezmény szabályozása kizárólag a fogalmi rendszer felépítésére támaszkodik. Emiatt pedig nagy különbségek fedezhetők fel az egyes belső jogszabályok között. Vannak például olyanok, amelyek kizárólag az UNCLOS 101. cikkére hagyatkoznak, mint olyan szabályra, amely tartalommal tölti meg a nemzetek jogában foglalt kalózkodás-tilalmat; vannak, amelyek az egyezmény szövegét veszik át szóról szóra; illetőleg olyanok is, amelyek csak tengeren elkövetett rablásként kezelik azt. Az ENSZ Biztonsági Tanácsa 2015-ben felhívta ugyan az államokat a tengeri kalózkodás belső jogban való büntetésére, de azt a VII. fejezetre való hivatkozás nélkül tette, az UNCLOS hiányosságai miatt pedig az államok sem támaszkodhatnak kizárólagosan az egyezményre. ${ }^{37}$

\section{A kalózkodás felderítését irányzó gyakorlati szabályok az UNCLOS-ban}

\subsection{A kalózhajó elfogása és az elfogást foganatositó jármüvek}

Az UNCLOS 105. cikke szerint a nyílt tengeren, vagy egyik állam joghatósága alatt sem álló területen bármely állam elfoghatja a kalózhajót, letartóztathatja a fedélzeten lévőket és elkobozhatja az ott található vagyontárgyakat. A cikk azt is kimondja, hogy az elfogást végrehajtó állam bíróságai dönthetnek a kiszabandó büntetésekről és alkalmazandó intézkedésekröl. ${ }^{38}$ Ezzel tehát az egyezmény is megerősíti a tengeri kalózkodás univerzális joghatóság alá tartozását.

Az UNCLOS továbbá azt is kimondja, hogy az elfogást csak hadihajók, katonai légi jármüvek vagy más olyan hajók, illetve légi jármüvek hajthatják végre, amelyek felismerhetően és azonosíthatóan állami szolgálatban állnak, és rendelkeznek az ehhez szükséges felhatalmazással. ${ }^{39}$ Emellett arról is rendelkezik, hogy jogalap nélküli elfogásért az elfogó állam kártérítést köteles fizetni. ${ }^{40}$ Ezzel kívánja elejét venni annak, hogy azok az államok, amelyek előszeretettel állítanak meg kereskedelmi hajókat a partjaikhoz közeli nyílt tengeren, ne okozzanak szükségtelen károkat a nemzetközi tengeri kereskedelemnek. ${ }^{41}$

\footnotetext{
37 BOISTER: i. m., 52.

${ }^{38}$ Az ENSZ Tengerjogi Egyezménye 105. cikk.

${ }^{39}$ Az ENSZ Tengerjogi Egyezménye 107. cikk.

${ }^{40}$ Az ENSZ Tengerjogi Egyezménye 106. cikk.

41 Hodgkinson: i. m., 24.
} 


\section{2. Átvizsgálási jog}

Az UNCLOS 110. cikke szól az átvizsgálási jogról, amely felhatalmazza a hadihajókat, hogy nyílt tengeren - kivéve, ha a hajó egy másik szerződés alapján teljes mentességet élvez - átvizsgálják azt a hajót, amellyel kapcsolatban annak alapos gyanúja merül fel, hogy valamilyen, a cikkben rögzített nemzetközi jogi szabályt sért, például kalózkodással vagy rabszolga-kereskedelemmel foglalkozik. ${ }^{42}$

A hadihajó ellenőrizheti a gyanús hajó lobogóviselési jogosultságát, majd amenynyiben a gyanú továbbra is fennmarad, egy tiszt vezetésével csónakot küldhet át a hajóokmányok ellenőrzésére és a fedélzet átvizsgálására. Fontos, hogy amenynyiben az átvizsgáláshoz való jogot csak erőszak alkalmazásával lehetséges gyakorolni a kalózok letartóztatása vagy a gyanús hajó tevékenységének megfigyelése céljából, a hadihajónak főszabály szerint a Webster-formula által meghatározott szükségességi-arányossági teszt figyelembevételével kell eljárnia ${ }^{43}$ amely azonban a gyakorlatban nem mindig biztosítható. Amennyiben a gyanú nem igazolódik be, a megvizsgált hajó tulajdonosát valamennyi elszenvedett veszteségért vagy kárért kártalanítani kell. ${ }^{44}$

\subsection{Az üldözés joga}

Az UNCLOS 111. cikke szerint azon állam haditengerészete vagy légiereje, amelynek alapos oka van feltételezni, hogy a területén jogsértést követtek el, megkezdheti az üldözést a saját területi vizein, és akkor folytathatja azt, ha az üldözés folyamata nem szakad meg. Az üldözés joga azonban megszűnik, ha az idegen jármű belép a saját állama vagy egy harmadik állam területi vizeire. ${ }^{45}$ Tehát az UNCLOS 111. cikke szerint az üldözéshez való jog csak akkor gyakorolható, ha a jármủ a nyílt tengeren vagy olyan helyen található, amely egyik állam joghatósága alá sem tartozik.

A kalózkodás által leginkább veszélyeztetett térségek közül Délkelet-Ázsiában és a Guineai-öbölben a támadások jelentős részét parti tengeren vagy folyótorkolatokban követik el. Különösképpen igaz ez az elöbbi régióra, amelyben a földrajzi adottságok következtében nyílt tengerrészek nem igazán vannak, ugyanis az államok föként a parti tengereiken határosak egymással, így könnyen előfordulhat olyan eset, amikor egy kalózhajó támadás és menekülés közben akár három különböző ország területi vizein is áthalad. Ahogy a fenti szabályozásból látható, ezekben az esetekben a bűnüldöző hatóságok mozgástere igencsak korlátozott, ami szintén az UNCLOS komoly negatívumaként jegyezhető fel. A 111. cikk nyilvánvalóan azért rendelkezik így, mert az egyezmény eleve úgy határozza meg a kalózkodást, hogy az csak nyílt tengeren követhetö el.

${ }^{42}$ Az ENSZ Tengerjogi Egyezménye 110. cikk (1) bekezdés.

${ }^{43}$ Lanuza Avello: i. m., 30.

${ }^{44}$ Az ENSZ Tengerjogi Egyezménye 110. cikk (3) bekezdés.

${ }^{45}$ Az ENSZ Tengerjogi Egyezménye 111. cikk (1); (3) bekezdés. 
A szabályozás hiányosságai feloldhatók például a bűnüldöző szervek szorosabb együttműködésével, amelynek alapjául bilaterális vagy multilaterális szerződések szolgálhatnak. A már említett Délkelet-Ázsiában számos ilyen megállapodást kötöttek az érintett államok, s ezeknek köszönhetően a támadások száma jelentősen csökkent. Malajzia, Szingapúr és Indonézia 2004-ben határozott a Malaka-szorosban történő, összehangolt járőrözésről, ami a MALSINDO nevet kapta. Ezt két évvel később kiterjesztették a légi járörözésre is. Végül ez a két kezdeményezés Malakaszorosi Járör Hálózat (Malacca Straits Patrol Network) néven olvadt össze. ${ }^{46} \mathrm{~A}$ közös szabályok megalkotása során természetesen az üldözés jogára is kitértek: az üldözés a másik szerződő állam területi vizein is biztosított, amennyiben az üldöző hatóság elöbb engedélyt kér attól az államtól, amelynek területére be fog lépni. ${ }^{47}$

Az üldözés jogának szabályozása viszont nemcsak a kalózok elfogására van negatív hatással, hanem más transznacionális büncselekményeket elkövetők felelösségre vonásának is gátja. Ezzel szembesült az Egyesült Államok a kábítószer-csempészet elleni küzdelem során. A problémát úgy oldotta meg, hogy bilaterális, ún. shiprider egyezményeket kötött Kanadával és a karibi államokkal. E szerződések lényege, hogy egy adott állam járöröző hadihajójának fedélzetén ott tartózkodik a másik vagy a többi szerződő állam bủnüldöző szervének tagja - ő a shiprider -, akinek hivatalos személyként joga van megadni az engedélyt a saját állama területére való belépésre az üldöző hajónak, így elkerülve az esetleges időveszteséget, amelyet a hatóságok közti kommunikáció okozna. A hivatalos személyi minőség abból a szempontból is előnyös, hogy a shiprider képes olyan feladatokat ellátni, amit egy haditengerész nem feltétlenül tudna (például a helyszín biztosítása, bizonyítékok összegyűjtése). ${ }^{48}$

A problémára tehát itt is találtak megoldást, de jól látható, hogy az UNCLOS szabályozásának hiányosságai nem csak a kalózkodás fogalma terén mutatkoznak meg, így más rendelkezéseinek felülvizsgálata is szükséges lenne.

\section{Az Achille Lauro incidens}

Ahogy azt már korábban említettem, az UNCLOS fogalmából eredő hátrányokra az Achille Lauro incidens hívta fel a figyelmet, ezáltal nagyban hozzájárulva a SUA létrejöttéhez. Az ügy rávilágít arra, hogy hogyan lehet elkerülni a kalózkodás vádját a két hajó követelménye jelenlegi szabályozásának köszönhetően.

Az Achille Lauro egy olasz turistahajó volt, amelyet 97 utassal a fedélzetén a palesztin felszabadítási mozgalom négy tagja térített el 1985. október 7-én, az egyiptomi Alexandriánál. Céljuk az volt, hogy Izrael szabadon engedje több társukat, akiket terrorizmussal vádoltak. Az elkövetők álruhában, utasként szálltak a hajóra és térítették el azt, akciójuk során pedig egy amerikai állampolgárságú utas vesztette

\footnotetext{
${ }^{46}$ LISS, Carolin: Assessing Contemporary Maritime Piracy in Southeast Asia: Trends, Hotspots and Responses. Peace Research Institute Frankfurt Report No. 125, 2014, 10.

${ }^{47}$ Mulyono, Hersapta: The Need to Enchance Regional Effort to Combat Piracy and Armed Robbery Against Ships in Southeast Asia. Indonesian Journal of International Law, 2014/1, 80.

${ }^{48}$ Mulyono: i. m., 80-81.
} 
életét. A hajóval előbb Szíria partjainál, majd Cipruson akartak kikötni, de nem kaptak rá engedélyt. Végül október 9-én az egyiptomi Port Said kikötőjében adták meg magukat a helyi hatóságoknak, és engedték el a túszokat, amnesztiáért cserébe. ${ }^{49}$

Október 10-én tértek volna vissza Palesztinába az egyiptomi légitársaság egyik gépén. Ronald Reagan amerikai elnök azonban közbelépett, és vadászgépeket küldött a repülő eltérítésére, amelyet végül egy szicíliai NATO-bázisra kísértek. Az elkövetőket letartóztatták, a palesztin felszabadítási front egyik vezetőjét - aki korábban részt vett a tárgyalásokban - azonban szabadon engedték. Az olasz bíróság végül 1986-ban ítélte el a támadásban részt vevő tetteseket - túszszedésért és emberölésért - 15 és 30 év közötti szabadságvesztésre. A már említett vezetőt pedig végül távollétében életfogytiglani szabadságvesztésre ítélték az akció kitervelése miatt. ${ }^{50}$

\section{A SUA}

A tengeren elkövetett jogellenes cselekmények visszaszorítását célzó jogi rezsim másik fő bástyája a SUA, ${ }^{51}$ amelyet - egy kiegészítő jegyzőkönyvvel együtt - 1988ban fogadtak el Rómában, és jelenleg 166 részes állama van. Az egyezményhez 2005-ben egy további kiegészítő jegyzőkönyvet füztek, amelynek 156 állam a részese. ${ }^{52}$ Elmondható tehát, hogy a dokumentum az UNCLOS-hoz hasonlóan széles körű elfogadottsággal rendelkezik a nemzetközi közösségen belül. A SUA hatékonyabb szabályozással rendelkezik a tengeren elkövetett büncselekmények terén, mint a tengerjogi egyezmény. Emiatt pedig az ENSZ Biztonsági Tanácsa is arra ösztönözte az államokat, hogy minél hamarabb csatlakozzanak a SUA-hoz. ${ }^{53}$

\subsection{A szabályozott deliktumok köre}

Habár a SUA konkrétan nem rendeli büntetni a tengeri kalózkodást, hanem egy sor, a tengerhajózás biztonsága elleni, elsősorban terrorista jellegü büncselekményt szabályoz, a benne foglalt definíciók elég tágan értelmezhetők ahhoz, hogy a kalózkodásra is kiterjeszthetők legyenek.

A SUA 3. cikke szerint bármely személy büncselekményt követ el, aki jogellenesen és szándékosan

a) hajót erőszakkal, fenyegetéssel vagy a megfélemlítés bármilyen más formájával hatalmába kerít, vagy ellenőrzését magához ragadja; vagy

${ }^{49}$ US Navy fighter jets intercept Italian cruise ship hijackers, https://www.history.com/this-day-in-history/achillelauro-hijacking-ends (2019. 12. 30.).

${ }^{50}$ US Navy fighter jets intercept Italian cruise ship hijackers, https://www.history.com/this-day-in-history/achillelauro-hijacking-ends (2019. 12. 30.).

${ }^{51}$ A tengerhajózás biztonsága elleni jogellenes cselekmények visszaszoritásáról szóló egyezmény (a továbbiakban: SUA). Magyarországon kihirdette: a 2003. évi LXVIII. törvény.

52 International Maritime Organization Status of Treaties., http://www.imo.org/en/About/Conventions/StatusOf Conventions/Documents/StatusOfTreaties.pdf (2019. 12. 28.).

${ }^{53}$ LANUza AVello: i. m., 49. 
b) a hajón tartózkodó személy ellen erőszakos cselekményt hajt végre, ha ez a cselekmény a hajó biztonságos hajózását valószínüsíthetően veszélyezteti; vagy

c) úgy rongál meg hajót vagy annak rakományát, illetve tesz kárt azokban, hogy az a hajó biztonságos hajózását valószínűsíthetően veszélyezteti; vagy

d) hajón, bármilyen módon olyan készüléket vagy anyagot helyez vagy helyeztet el, amely valószínüsíthetően a hajót elpusztítja, vagy olyan kárt okoz a hajóban vagy annak rakományában, amely a hajó biztonságos hajózását veszélyezteti vagy valószínüsíthetően veszélyezteti; vagy

e) tengeri hajózási létesítményeket lerombol vagy súlyosan megrongál, illetőleg azok müködését súlyosan zavarja, amennyiben az ilyen cselekmény a hajó biztonságos hajózását valószínúsíthetően veszélyezteti; vagy

f) a hajó biztonságos hajózását veszélyeztetve olyan információt közöl, amelyröl tudja, hogy téves; vagy

g) az a)-f) pontokban megnevezett büncselekmény elkövetésével vagy kísérletével összefüggésben bárki testi épségét sérti, vagy bárkit megöl.

A felsoroltakon kívül a SUA büntetni rendeli a részesi magatartásokat, illetve a kísérletet is. Söt, a b), c) és e) pontban foglalt cselekmények esetében azt is, ha az elkövető valakit arra kényszerít, hogy a három deliktum elkövetése érdekében valamit tegyen, vagy ne tegyen, ha a fenyegetés alkalmas a hajó biztonságos hajózásának veszélyeztetésére. Jól látható tehát, hogy az egyezmény számos olyan bűncselekményt lefed, amelyeket tipikusan a kalózok is elkövetnek támadásaik során. Ez azt is jelenti, hogy a SUA alapján a kalózok felelősségre vonására akkor is sor kerülhet, ha az UNCLOS definíciójában támasztott feltételek valamelyike nem teljesülne, így az alapján az eset nem minősülne kalózkodásnak.

Ugyanakkor - amint azt már említettem - az UNCLOS-ban meghatározott kalózkodás univerzális joghatóság alá tartozik, ez pedig nem igaz a SUA által szabályozott bủncselekményekre. Ahhoz, hogy valamelyik állam eljárhasson ezek kapcsán, az szükséges, hogy vagy a területi vizein kövessék el a deliktumot, vagy az extraterritoriális joghatóság feltételeinek kell fennállnia. ${ }^{54}$ Tehát az adott állam jogosult lesz eljárni akkor is, ha a bủncselekményt ugyan nem a területén követik el, vagy nem az állampolgárát érinti, de az államra is hatással van, hiszen veszélyezteti a közrendjét vagy közbiztonságát.

\subsection{Eltérések az UNCLOS szabályozásához képest}

A SUA egyik legjelentősebb szabályozási pontja, hogy az általa szabályozott cselekmények nem kötődnek földrajzi tényekhez, ezáltal a parti tengeren is elkövethetők, ${ }^{55}$ ugyanakkor ezzel kapcsolatosan felállít egy korlátozást is: az egyezményt csak akkor lehet alkalmazni, ha a megtámadott hajó „az egyes állam parti tengeré-

\footnotetext{
54 HOdGKINSON: i. m., 26.

55 LATTMANN Tamás: A szomáliai kalózkodás kérdése a nemzetközi jogban és azon túl. Nemzet és Biztonság, 2010/9, 68-69.
} 
nek külső határán, vagy pedig a szomszédos államok parti tengerének oldalhatárain kívülre, azon keresztül vagy onnan hajózik, illetve tervez hajózni”. ${ }^{56}$ Ez tehát azt jelenti, hogy a parti tengerhez füződő területi hatály csak akkor áll fenn, ha a megtámadott hajó a támadás során éppen a parti tengeren kívülre tartott, vagy betervezett úti célja a parti tengeren kívülre vezetett. A SUA területi hatálya így sokkal tágabb, mint az UNCLOS-é, de még így is tartalmaz megszorító rendelkezéseket. Hiszen sem a SUA, sem az UNCLOS rendelkezései nem terjednek ki azokra az esetekre, amikor például az elkövetés helye a kikötő, vagy ha a hajó kizárólag egyazon állam parti tengerein haladt, mert két kikötőváros között szállított árut. ${ }^{57}$ Utóbbi esetben viszont a hajók elleni fegyveres rablás szabályai fennállhatnak.

A SUA fontos újítása az is, hogy nem tartalmazza a két hajó követelményét, ezáltal jelentősen kiterjeszti azoknak az eseteknek a körét, amikor az egyezmény alapján el lehet járni. Ezáltal az egyezmény hatálya alá kerülnek azok a támadások is, amiket a szárazföldröl vagy a kikötöből követnek el, sőt akkor is alkalmazható lesz az egyezmény, ha például az elkövetők búvárruhában közelítik meg a hajót. ${ }^{58}$ Emellett a két hajó követelményének a mellőzése akkor is jelentőséget nyerhet, ha a támadók hajónak nem tekinthető vízi járművet (például tutajt) használnak.

Az egyezmény továbbá a magáncélból történő elkövetés követelményét sem szabja feltételként, hiszen csak azt határozza meg, hogy az adott büncselekményt jogellenesen és szándékosan kell elkövetni. Ezáltal pedig a SUA hatálya alá tartoznak azok a deliktumok is, amelyeket politikai vagy ideológiai célból követnek el, ${ }^{59} \mathrm{ez}$ utóbbiak pedig egyértelmủen a terrorista jellegủ cselekmények sajátjai. A szabályozás köre tehát ebben az esetben is tágabb, mint az UNCLOS-é.

A SUA nem ismeri az átvizsgálási jogot, ugyanakkor lehetőséget biztosít a jogellenes cselekményt elkövető hajó elfogására abban az esetben, ha az elfogást végrehajtó hajó tanúja volt annak, hogy elöbbi az egyezmény hatálya alá tartozó valamelyik bủncselekményt elkövette. Ezzel kapcsolatos korlátozás, hogy ha az elfogást foganatosító hajó nem a lobogója szerinti állam területi vizein tevékenykedik, akkor elöbb engedélyt kell kérnie a jogsértést elkövető hajó lobogója szerinti államtól, vagy közvetlen kapcsolatban kell állnia a jogsértő hajóval vagy a jogellenes magatartással. A SUA szabályai tehát az elfogás és a nyomozás terén szükebbek az UNCLOS rendelkezéseinél, amely az elfogást foganatosító hajónak feltétel nélkül engedélyezi az elfogást, amennyiben tanúja volt kalózcselekmény elkövetésének. ${ }^{60}$

Rendelkezéseit tekintve a SUA tipikusan olyan visszaszorító egyezmény, amelyet a nemzetközi közösség a transznacionális bủncselekmények elleni küzdelem jegyében szokott elfogadni. Az 5. cikk konkrétan kimondja az államok kötelezettségét, hogy büntetendővé kell nyilvánítaniuk az általa szabályozott deliktumokat, illetve arról is gondoskodniuk kell, hogy belső joguk megfelelően büntesse azokat. További eltérés az UNCLOS-hoz képest, hogy a SUA a büntetőeljárások lefolytatásával kapcsolatos rendelkezéseket is tartalmaz. ${ }^{61}$

\footnotetext{
56 SUA 3. cikk.

${ }^{57}$ BOIsTER: i. m., 53.

58 Hodgkinson: i. m., 29.

59 Hodgkinson: i. m., 28-29.

60 HodgKINSON: i. m., 30.

61 LaNuza Avello: i. m., 51.
} 
Fontos ugyanakkor kiemelni, hogy a SUA megalkotásának nem az volt a célja, hogy szabályai felváltsák az UNCLOS-t, hanem hogy kiegészítsék, pótolják azokat. Így például, ha egy hajó legénysége ellopja egy másik hajó rakományát, ám anélkül, hogy veszélyeztetné utóbbi jármú biztonságát, az továbbra is az UNCLOS szerinti kalózkodásnak minősül, nem pedig a SUA által szabályozott valamelyik büncselekménynek. A két egyezmény tehát egymással szoros szimbiózisban létezik, hiszen a tengerhajózás során elkövetett jogellenes cselekmények visszaszorítását önmagában egyik sem tudná biztosítani. ${ }^{62}$

\section{Konklúzió}

A tengeri kalózkodás nemzetközi jogi szabályozásának egyik fő eleme az ENSZ Tengerjogi Egyezménye, amelynek 101. cikke egyetemesen elfogadottnak számít. Ugyanakkor az ebben adott definíció számos aggályos kérdést vet föl. Az egyik ilyen szabály a két hajó követelményének felállítása, amelynek problémás voltát kiválóan igazolta az Achille Lauro incidens. Emellett az egyezmény a kalózkodás feltételeként határozza meg a magáncélból történő elkövetést, aminek pontos tartalmát ugyanakkor nem részletezi, ez pedig számos hibás bírósági döntést szült és fog szülni a jövőben is. Szintén aggályos, hogy az UNCLOS fogalma szerint a kalózkodás elkövetési helye a nyílt tengerre korlátozódik, hiszen a támadások többségét a parti tengereken követik el.

A Nemzetközi Tengerészeti Szervezet tevékenysége során igyekszik kiküszöbölni az egyezmény fogalmi hiányosságait. Azonban a SUA rendelkezései sem képesek valamennyi esetet lefedni, hiszen korlátozásokat tartalmaznak az elkövetési helyre vonatkozóan. Azt viszont kijelenthetjük, hogy a SUA nagyrészt képes arra, hogy betömje azokat a lyukakat, amiket az UNCLOS meghagyott. Szintén az IMO munkáját dicséri a hajók elleni fegyveres rablás kategóriájának megalkotása, amivel a két egyezmény által nem szabályozott eseteket kívánták lefedni. Ezáltal elmondható, hogy mind a kalózkodás fogalmára, mind pedig az elfogásra és az eljárások lefolytatására vonatkozó nemzetközi jogi szabályok kielégítőek, bár nem tökéletesek.

\footnotetext{
62 LaNuza Avello: i. m., 51.
} 